\title{
Exploring the Efficacy of Using Hypertonic Saline for Nebulizing Treatment in Children with Bronchiolitis: a Meta-Analysis of Randomized Controlled Trials
}

Chia-Wen Hsieh ( $\sim$ 103202@w.tmu.edu.tw )

Taipei Medical University https://orcid.org/0000-0001-6296-6853

Hui-Chuan Su

Taipei Medical University

Kee-Hsin Chen

Taipei Medical University

Chiehfeng Chen

Taipei Medical University

\section{Research article}

Keywords:

Posted Date: May 11th, 2020

DOI: https://doi.org/10.21203/rs.3.rs-27194/v1

License: (c) (i) This work is licensed under a Creative Commons Attribution 4.0 International License. Read Full License

Version of Record: A version of this preprint was published on September 14th, 2020. See the published version at https://doi.org/10.1186/s12887-020-02314-3. 


\section{Abstract}

Introduction: Acute bronchiolitis is the most common lower respiratory infection in children. It is particularly prone to dyspnea among children under two years old. Inhaled hypertonic saline (HS) has recently been shown to be a favorable therapy, because of its facility to draw fluid from the submucosa and adventitial spaces, decreasing airway edema. The aim of this systematic review and meta-analysis was to evaluate the efficacy and safety of HS in the implementation of vapor treatment among children with bronchiolitis.

Methods: A systematic literature search was conducted using Cochrane Library, PubMed, EMBASE and Airiti Library (Chinese Database) for randomized controlled trials from inception to July 2019. We calculated pooled risk ratios (RR), mean difference (MD) and 95\% Cl using RevMan 5.3 for meta-analysis.

Results: In total, 4186 children from 32 publications were included. Compared to the control group, the HS group exhibited significantly reducing the level of severity of respiratory distress, included studies used the Clinical Severity Score $(95 \% \mathrm{Cl}-1.15,-0.27, P=73 \%)$ and Respiratory Distress Assessment Instrument $(95 \% \mathrm{Cl}-0.95,-0.26, R=0 \%)$ for evaluation respectively. Further, the HS group decreased the length of hospital stay 0.54 days $(95 \% \mathrm{Cl}-0.86$, $-0.32, R=81 \%)$.

Conclusion: We conclude that nebulized with $3 \%$ saline solution is effective in decreasing the length of hospital stay and the severity of symptoms as compared with $0.9 \%$ saline solution among children with acute bronchiolitis. Further rigor randomize controlled trails with large sample size are needed.

\section{Background}

Bronchiolitis is the most common lower-respiratory infection in children, affecting $68.8 \%$ of infants and neonates aged $<12$ months $^{1-2}$, and is a major cause for hospitalization in children in the first year after birth. ${ }^{3-4}$ Bronchiolitis $^{3}$ is primarily caused by viral infection which results in inflammation of the bronchioles in the lungs. ${ }^{5-6}$ The infection can last $2 \sim 3$ weeks, and commonly causes pulmonary edema, mucosal congestion, and sputum during the disease course. $^{7-8}$ Common symptoms include excessive coughing accompanied with tachypnea, fever and wheezing. ${ }^{9-10}$

In some cases of severe nasal congestion, a child might need to resort to open-mouth breathing, and young children are particularly prone to dyspnea caused by tracheal obstruction, which may cause respiratory failure in severe cases. ${ }^{11-12}$ Infants may also be prone to vomiting milk due to frequent coughing during the night, which can affect their sleep quality, and in turn affect their activity and mental status during the day and is also closely related to recovery of the body's immune system. ${ }^{13-16}$

Approximately $50-80 \%$ of bronchiolitis are caused by infection by the respiratory syncytial virus (RSV), thereby deeming treatment with most medications, such as antibiotics, ineffective. ${ }^{17}$ According to the 2014 American Academy of Pediatrics Bronchiolitis guideline, the primary treatment method is supportive treatment such as encouraging rest, maintain nutrition intake, and fluid supplementation. ${ }^{18-19}$ For discomforting symptoms such as cough and fever, appropriate usage of supportive medication such as antipyretics, antitussive syrup, nebulization or oxygen supplementation can help relieve the symptoms. ${ }^{19-21}$

Usually, normal saline is employed as the diluent in nebulizers; the principle is that it uses oxygen flow to vaporize water molecules or drugs and allow these to be breathed in through the mouth and nose and spread to the 
respiratory tract and lungs with the airflow. After the alveolar capillaries absorb the molecules, the drugs then dilute the secretions in the respiratory tract, induce expectoration, and relieve symptoms of bronchospasm. ${ }^{22-23}$

Recently, several studies pointed out that hypertonic saline (3\%) is beneficial in inducing the penetration of water molecules into the lung mucosa, allowing the mucosal or submucosal layers to absorb water molecules and reduce the probability of edema of the airway. ${ }^{24-25}$ It also uses the principle of vaporization to moisturize the airway surface, increase mucosa cilia function, and accelerate elimination of obstructive sputum to achieve better treatment effects. $^{26}$

However, other studies also pointed out that there is no significant difference between the efficacy of hypertonic saline and normal saline nebulizers for treating children with bronchiolitis ${ }^{27-29}$, and there have always been differences in saline concentrations clinically used for nebulizing.

Zhang et al. (2017) published a systematic literature review and meta-analysis with results that demonstrated that the use of hypertonic saline can significantly shorten the length of hospital stay, but the article did not provide explanation for the highly heterogeneous results. ${ }^{30}$ Summarizing the above, the purpose of this study is to conduct a systematic review and meta-analysis of the latest randomized controlled trials (RCTs) to update the effectiveness and safety of using hypertonic saline (3\%) for nebulizing treatment in children with bronchiolitis, and we included results of a children's sleep index in the analysis, with the aim of providing a reference for clinical treatment.

\section{Methods}

\section{Database Searches}

We found Mesh terms and related synonyms through the PubMed Mesh Database and used Boolean logic to search for literature. Keywords and searching strategy were as follows: "bronchiolitis" OR "pediatrics" OR "child*" AND " $3 \%$ saline" OR "hypertonic saline" AND "saline solution" OR "0.9\% saline" OR "normal solution." The study screened the following online databases: Cochrane, PubMed, EMBASE, and Airiti Library. The search period was set to before July 2019, search results were limited to Chinese and English articles, and no limitations were set on the publication date. Additionally, we manually searched for literature cited in related systematic literature reviews and RCTs.

\section{Inclusion Criteria}

Two independent researchers (CW Hsieh and HC Su) screened the literature, and the inclusion criteria were as follows: (1) population: children aged < 18 years with bronchiolitis; (2) intervention: hypertonic saline (3\%); (3) control intervention: normal saline $(0.9 \%)$; (4) results: severity of respiratory distress, length of hospital stay (LOS), rate of hospitalization, rate of readmission, time of sleeping, frequency of waking up in the night, drug side effects, etc.; and (5) research method: RCTs.

Exclusion criteria included the following: patients with other comorbidities such as congenital respiratory tract disease, cardiac insufficiency and immunodeficiency.

During the screening process of browsing through the titles, abstracts, and full articles, any differing opinions that emerged were discussed with a third researcher (KH Chen or C Chen), and a consensus was achieved through discussion. 


\section{Literature quality assessment}

Two researchers (CW Hsieh and HC Su) used the Cochrane risk of bias tool (RoB) 2.0 to independently conduct a literature risk assessment (Higgins et al., 2011). The five fields for assessment included (1) Bias arising from the randomization process; (2) bias due to deviations from intended interventions; (3) bias due to missing outcome data; (4) bias in measurement of the outcome; and (5) bias in selection of the reported result. The assessment results were rated as low, some concern, and high risk of bias. According to suggestions by the Cochrane handbook for systematic reviews of interventions, if any one of the fields in the result indices were assessed as having high risk of bias, then the overall assessment of the study would be labeled as high risk.

Next, the Grading of Recommendations Assessment, Development and Evaluation (GRADE) system was used for assessing the evidence body of the included meta-analytical results. Trials included by this study were randomized controlled trials; therefore, the preliminary assessment for evidence level was high, and the assessment was graded based on five downgrade factors, which included risk of bias, inconsistency, indirectness, imprecision, and publication bias. The final quality of evidence was graded as either a high, moderate, low, or very low level. Finally, clinical recommendations were formed according to factors such as the strength of the evidence, clearness of intervention pros and cons, patient preference, and resources, and the recommendation strength was graded as either strong or weak (GRADE Working Group, 2017).

\section{Data Analysis}

Two researchers (CW Hsieh and $\mathrm{HC} \mathrm{Su}$ ) independently extracted research data and conducted a meta-analysis using the Revman 5.3 software (The Nordic Cochrane Centre, Copenhagen, Denmark, 2014). Mean and standard deviation (SD) values were extracted for continuous data, and number of people in each group and number of incidences were extracted to analyze categorical data. The Cochrane $\mathrm{Q}$ and $R$ tests were used to assess heterogeneity. When the $\mathrm{Q}$ value showed significant difference $(p<0.1)$, it was considered that there existed heterogeneity in the study samples. The $R$ test was used to determine the level of heterogeneity between the study samples, and the final results were collectively portrayed in a forest plot to exhibit the effect size and 95\% confidence interval (Cl).

\section{Sensitivity Analysis}

The meta-analysis results were cautiously assessed, and if high heterogeneity was noted among the results, then sensitivity and subgroup analyses were conducted. Subgroups were divided based on factors such as the study's research region, hospitalization, and LOS, and the obtained results were compared with results before subgrouping to confirm the stability of the meta-analytical results.

\section{Results}

\section{Literature search results}

In total, 1423 articles were found in the databases, and three articles were manually searched; 1033 articles remained after 393 duplicate articles were excluded; 859 articles were excluded after the titles and abstract were read and determined to be incompatible with the study; and 174 articles were included for careful examination of the full texts. Screening was done according to preset inclusion-exclusion criteria; finally, 32 RCTs ${ }^{8,28-29,31-59}$ along with 
31 studies were included in the meta-analysis. Details of the search and screening process of articles and reasons for exclusion are presented in Fig. 1.

\section{Characteristics Of Included Studies}

Of the 32 selected RCTs, 20 (62.5\%) were conducted in the Asian region, and six (18.8\%) were conducted in the Americas or European countries. Regarding the research setting, 22 (68.8\%) studies were conducted in hospital wards with study targets being hospitalized children, and 10 studies (31.3\%) were conducted in emergency wards of outpatient departments.

All 4186 included subjects were diagnosed with acute bronchiolitis, 70.5\% of subjects had RSV infection, two had a past history of asthma, 2100 (50.2\%) were treated with hypertonic saline (3\%), and $2086(49.8 \%)$ were treated with normal saline. The mean age of the two population groups were 6.3 months vs. 6.5 months, the sex ratio were $58.3 \%$ males vs. $41.7 \%$ females, and there were no significant differences regarding the age or sex between these two groups $(p>0.05)$. Dosages of saline used for nebulizing treatment differed according to each study's design, and the dosage used ranged $2 \sim 5 \mathrm{~mL}$. Regarding required treatments according to different clinical symptoms, 22 studies (68.8\%) combined treatment with epinephrine, bronchodilators, or steroids. The basic characteristics of the included studies are summarized in Table 1. 
Table 1

Characteristics of the included trials.

\begin{tabular}{|c|c|c|c|c|c|c|c|}
\hline Study & Patients & & Intervent & & Compariso & & Outcome \\
\hline year & & $\begin{array}{l}\text { Average } \\
\text { age (male } \\
\% \text { ) }\end{array}$ & $3 \% \mathrm{H} / \mathrm{S}$ & $\begin{array}{l}\text { Additional } \\
\text { drugs }\end{array}$ & $0.9 \% \mathrm{~N} / \mathrm{S}$ & $\begin{array}{l}\text { Additional } \\
\text { drugs }\end{array}$ & \\
\hline Country & & $\begin{array}{l}\text { RSV } \\
\text { positive } \\
\text { rate }\end{array}$ & & & & & \\
\hline $\begin{array}{l}\text { Al-Ansari et al. } \\
2010 \\
\text { [?]Saudi Arabia }\end{array}$ & $\begin{array}{l}<18 \text { mon } \\
\text { Inpatients } \\
n=114\end{array}$ & $\begin{array}{l}3.9 \text { mon } \\
(59.1 \%) \\
\text { No } \\
\text { information }\end{array}$ & $\begin{array}{l}5 \mathrm{~mL}(n \\
=58)\end{array}$ & $\begin{array}{l}+1.5 \mathrm{mg} \\
\text { epinephrine }\end{array}$ & $\begin{array}{l}5 \mathrm{~mL}(n= \\
56)\end{array}$ & $\begin{array}{l}+1.5 \mathrm{mg} \\
\text { epinephrine }\end{array}$ & $\begin{array}{l}\text { LOS } \\
\text { CSS }\end{array}$ \\
\hline $\begin{array}{l}\text { Angoulvant et } \\
\text { al. } \\
2017 \\
\text { France }\end{array}$ & $\begin{array}{l}6 \mathrm{wk} \sim 12 \\
\text { mon } \\
\text { ED } \\
n=772\end{array}$ & $\begin{array}{l}3 \text { mon } \\
(60.2 \%) \\
86.4 \%\end{array}$ & $\begin{array}{l}4 \mathrm{~mL}(n \\
=385)\end{array}$ & & $\begin{array}{l}4 \mathrm{~mL}(n= \\
387)\end{array}$ & & $\begin{array}{l}\text { RDAl } \\
\text { ROH } \\
\text { Adverse } \\
\text { events }\end{array}$ \\
\hline Anil et al. & $\begin{array}{l}6 \mathrm{wk} \sim 24 \\
\text { mon } \\
\text { ED } \\
n=149\end{array}$ & $\begin{array}{l}9.5 \text { mon } \\
(64.5 \%) \\
\text { No } \\
\text { information }\end{array}$ & $\begin{array}{l}\text { 1) } 4 \mathrm{~mL} \\
(n=39) \\
\text { 2) } 4 \mathrm{~mL} \\
(n=36)\end{array}$ & $\begin{array}{l}+1.5 \mathrm{mg} \\
\text { epinephrine } \\
+2.5 \mathrm{mg} \\
\text { salbutamol }\end{array}$ & $\begin{array}{l}\text { 1) } 4 \mathrm{~mL} \\
(n=38) \\
\text { 2) } 4 \mathrm{~mL} \\
(n=36)\end{array}$ & $\begin{array}{l}+1.5 \mathrm{mg} \\
\text { epinephrine } \\
+2.5 \mathrm{mg} \\
\text { salbutamol }\end{array}$ & $\mathrm{ROH}$ \\
\hline $\begin{array}{l}2010 \\
\text { Turkey }\end{array}$ & & & & & & & ROR \\
\hline $\begin{array}{l}\text { Everard et al. } \\
2014 \\
\text { UK }\end{array}$ & $\begin{array}{l}<12 \text { mon } \\
\text { Inpatients } \\
n=291\end{array}$ & $\begin{array}{l}3.4 \text { mon } \\
(54.5 \%) \\
61.5 \%\end{array}$ & $\begin{array}{l}4 \mathrm{~mL}(n \\
=142)\end{array}$ & $\begin{array}{l}\text { + standard } \\
\text { care }\end{array}$ & $\begin{array}{l}(n=149) \\
\text { *Nebulizer } \\
\text { use not } \\
\text { reported }\end{array}$ & $\begin{array}{l}\text { + standard } \\
\text { care }\end{array}$ & $\begin{array}{l}\text { LOS } \\
\text { RDAI }\end{array}$ \\
\hline
\end{tabular}

1. ED, emergency department; OPD, outpatient department; RSV, respiratory syncytial virus.

2. $3 \% \mathrm{HS}, 3 \%$ hypertonic saline; $0.9 \% \mathrm{NS}, 0.9 \%$ normal saline.

3. Epinephrine: Adrenaline; Atrovent, Salbutamol, Albuterol, Terbutaline: Bronchodilator; Budesonide: Corticosteroids.

4. CSS, clinical severity score; RDAl, respiratory distress assessment instrument; LOS, length of hospital stay; $\mathrm{ROH}$, rate of hospitalization; ROR, rate of re-admission; TOS, time of sleeping; FOWITN, frequency of waking up in the night. 


\begin{tabular}{|c|c|c|c|c|c|c|c|}
\hline \multirow{3}{*}{$\begin{array}{l}\text { Study } \\
\text { Flores et al. } \\
2016\end{array}$} & \multicolumn{2}{|l|}{ Patients } & \multicolumn{2}{|c|}{ Intervention } & \multicolumn{2}{|c|}{ Comparison } & \multirow{3}{*}{$\begin{array}{l}\text { Outcome } \\
\text { LOS } \\
\text { CSS }\end{array}$} \\
\hline & \multirow{2}{*}{$\begin{array}{l}<12 \text { mon } \\
\text { Inpatients }\end{array}$} & \multirow{2}{*}{$\begin{array}{l}3.6 \text { mon } \\
(52.9 \%) \\
85.4 \%\end{array}$} & \multirow{2}{*}{$\begin{array}{l}3 \mathrm{~mL}(n \\
=33)\end{array}$} & \multirow{3}{*}{$\begin{array}{l}+1.25 \mathrm{mg} \\
\text { salbutamol }\end{array}$} & \multirow[t]{2}{*}{$\begin{array}{l}3 \mathrm{~mL}(n= \\
35)\end{array}$} & \multirow{3}{*}{$\begin{array}{l}+1.25 \mathrm{mg} \\
\text { salbutamol }\end{array}$} & \\
\hline & & & & & & & \\
\hline Portugal & \multicolumn{2}{|l|}{$n=68$} & & & & & \\
\hline \multirow{3}{*}{$\begin{array}{l}\text { Florin et al. } \\
2014 \\
\text { USA }\end{array}$} & $\begin{array}{l}2 \sim 24 \\
\text { mon }\end{array}$ & $\begin{array}{l}6.7 \text { mon } \\
(45.2 \%)\end{array}$ & \multirow[t]{3}{*}{$\begin{array}{l}4 \mathrm{~mL}(n \\
=31)\end{array}$} & & \multirow[t]{3}{*}{$\begin{array}{l}4 \mathrm{~mL}(n= \\
31)\end{array}$} & & $\mathrm{ROH}$ \\
\hline & ED & \multirow{2}{*}{$\begin{array}{l}\text { No } \\
\text { information }\end{array}$} & & & & & \\
\hline & $n=62$ & & & & & & \\
\hline \multirow{3}{*}{$\begin{array}{l}\text { Grewal et al. } \\
2009 \\
\text { Canada }\end{array}$} & \multirow{3}{*}{$\begin{array}{l}6 \mathrm{wk} \sim 12 \\
\mathrm{mon} \\
\mathrm{ED} \\
n=46\end{array}$} & \multirow{3}{*}{$\begin{array}{l}5 \text { mon } \\
(60.9 \%) \\
82.2 \%\end{array}$} & \multirow{3}{*}{$\begin{array}{l}2.5 \mathrm{~mL} \\
(n=23)\end{array}$} & \multirow{3}{*}{$\begin{array}{l}+0.5 \mathrm{~mL} \\
2.25 \% \\
\text { epinephrine }\end{array}$} & \multirow{3}{*}{$\begin{array}{l}2.5 \mathrm{~mL}(n \\
=23)\end{array}$} & \multirow{3}{*}{$\begin{array}{l}+0.5 \mathrm{~mL} \\
2.25 \% \\
\text { epinephrine }\end{array}$} & RDAI \\
\hline & & & & & & & $\mathrm{ROH}$ \\
\hline & & & & & & & ROR \\
\hline \multirow{4}{*}{$\begin{array}{l}\text { Hou et al. } \\
2016 \\
\text { China }\end{array}$} & \multirow{2}{*}{$\begin{array}{l}1 \sim 11 \\
\text { mon }\end{array}$} & \multirow{2}{*}{$\begin{array}{l}6 \mathrm{M} \\
(50.4 \%)\end{array}$} & $(n=17)$ & \multirow{2}{*}{$\begin{array}{l}+1.25 \mathrm{ml} \\
\text { atrovent }\end{array}$} & $(n=17)$ & \multirow{2}{*}{$\begin{array}{l}+1.25 \mathrm{ml} \\
\text { atrovent }\end{array}$} & LOS \\
\hline & & & \multirow{3}{*}{$\begin{array}{l}\text { *how } \\
\text { many } \\
\text { milliliters } \\
\text { not } \\
\text { reported }\end{array}$} & & \multirow{3}{*}{$\begin{array}{l}\text { *how } \\
\text { many } \\
\text { milliliters } \\
\text { not } \\
\text { reported }\end{array}$} & & TOS \\
\hline & Inpatients & $\begin{array}{l}\text { No } \\
\text { information }\end{array}$ & & \multirow{2}{*}{$\begin{array}{l}+1 \mathrm{ml} \\
\text { budesonide }\end{array}$} & & \multirow{2}{*}{$\begin{array}{l}+1 \mathrm{ml} \\
\text { budesonide }\end{array}$} & \\
\hline & $n=34$ & & & & & & \\
\hline \multirow{3}{*}{$\begin{array}{l}\text { Ipek et al. } \\
2011 \\
\text { Turkey }\end{array}$} & $<24$ mon & $\begin{array}{l}7.9 \text { mon } \\
(59.2 \%)\end{array}$ & $\begin{array}{l}\text { 1) } 4 \mathrm{~mL} \\
(n=30)\end{array}$ & \multirow{3}{*}{$\begin{array}{l}+ \\
0.15 \mathrm{mg} / \mathrm{kg} \\
\text { salbutamol }\end{array}$} & $\begin{array}{l}\text { 1) } 4 \mathrm{~mL} \\
(n=30)\end{array}$ & \multirow{3}{*}{$\begin{array}{l}+ \\
0.15 \mathrm{mg} / \mathrm{kg} \\
\text { salbutamol }\end{array}$} & \multirow[t]{3}{*}{$\mathrm{ROH}$} \\
\hline & ED & & 2) $4 \mathrm{~mL}$ & & 2) 4 & & \\
\hline & $n=120$ & information & $(n=30)$ & & $(n=30)$ & & \\
\hline
\end{tabular}

1. ED, emergency department; OPD, outpatient department; RSV, respiratory syncytial virus.

2. $3 \% \mathrm{HS}, 3 \%$ hypertonic saline; $0.9 \% \mathrm{NS}, 0.9 \%$ normal saline.

3. Epinephrine: Adrenaline; Atrovent, Salbutamol, Albuterol, Terbutaline: Bronchodilator; Budesonide: Corticosteroids.

4. CSS, clinical severity score; RDAl, respiratory distress assessment instrument; LOS, length of hospital stay; $\mathrm{ROH}$, rate of hospitalization; ROR, rate of re-admission; TOS, time of sleeping; FOWITN, frequency of waking up in the night. 


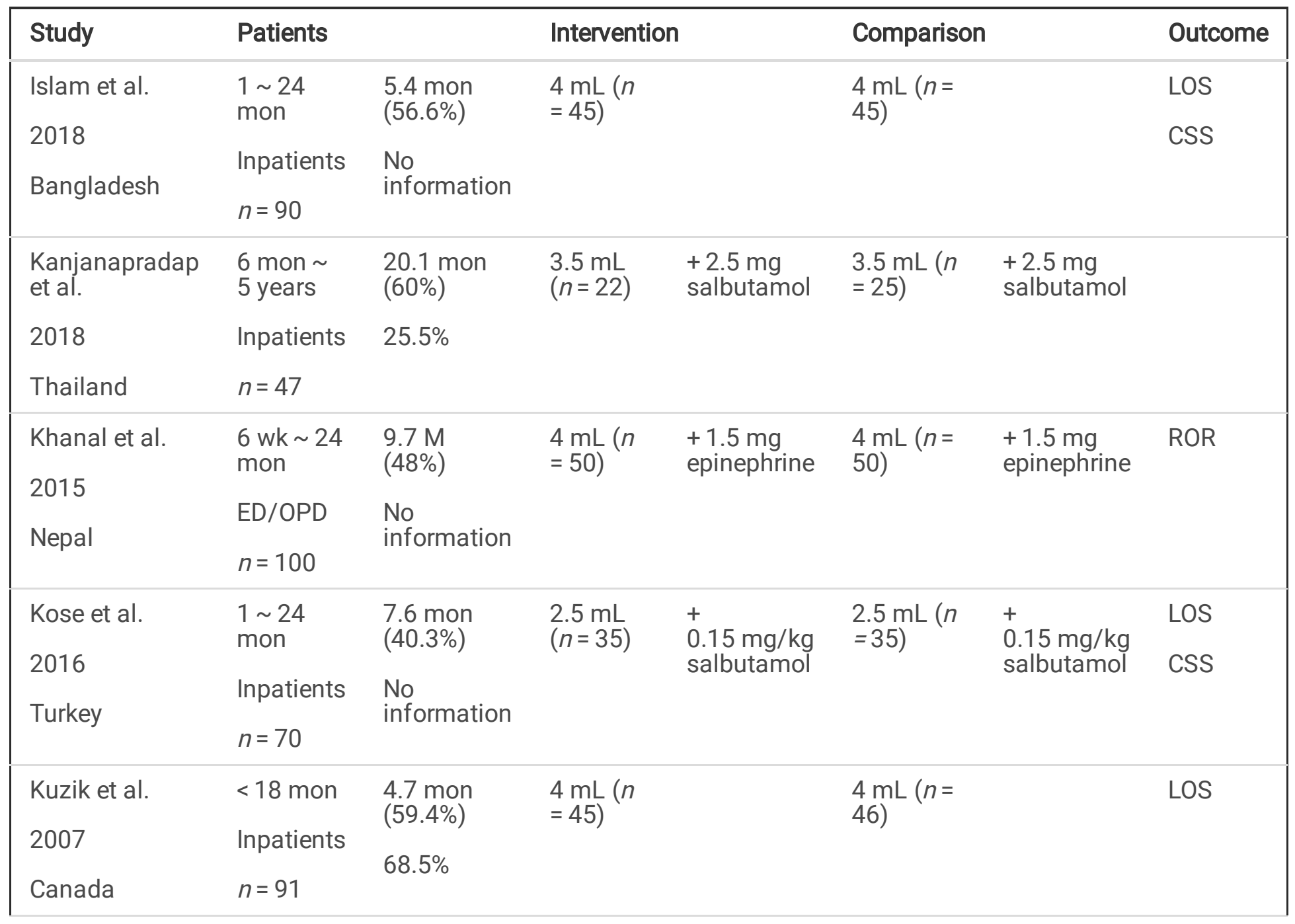

1. ED, emergency department; OPD, outpatient department; RSV, respiratory syncytial virus.

2. $3 \% \mathrm{HS}, 3 \%$ hypertonic saline; $0.9 \% \mathrm{NS}, 0.9 \%$ normal saline.

3. Epinephrine: Adrenaline; Atrovent, Salbutamol, Albuterol, Terbutaline: Bronchodilator; Budesonide: Corticosteroids.

4. CSS, clinical severity score; RDAl, respiratory distress assessment instrument; LOS, length of hospital stay; $\mathrm{ROH}$, rate of hospitalization; ROR, rate of re-admission; TOS, time of sleeping; FOWITN, frequency of waking up in the night. 


\begin{tabular}{|c|c|c|c|c|c|c|c|}
\hline Study & Patients & & Interventi & & Comparisc & & Outcome \\
\hline & $<24$ mon & $\begin{array}{l}8.9 \text { mon } \\
(77.5 \%)\end{array}$ & $\begin{array}{l}4 \mathrm{~mL}(n \\
=44)\end{array}$ & $\begin{array}{l}+1 \mathrm{mg} \\
\text { salbutamol }\end{array}$ & $\begin{array}{l}4 \mathrm{~mL}(n= \\
44)\end{array}$ & $\begin{array}{l}+1 \mathrm{mg} \\
\text { salbutamol }\end{array}$ & RDAl \\
\hline 2010 & ED & $47 \%$ & & & & & $\mathrm{ROH}$ \\
\hline Canada & $n=88$ & $\begin{array}{l}\text { History of } \\
\text { asthma }\end{array}$ & & & & & \\
\hline Li et al. & $\begin{array}{l}2 \sim 18 \\
\text { mon }\end{array}$ & $\begin{array}{l}7.2 \mathrm{mon} \\
(73.3 \%)\end{array}$ & $\begin{array}{l}2 \mathrm{~mL}(n \\
=42)\end{array}$ & & $\begin{array}{l}2 \mathrm{~mL}(n= \\
42)\end{array}$ & & cSS \\
\hline 2014 & OPD & No & & & & & \\
\hline Conna & $n=84$ & 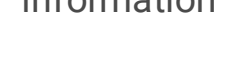 & & & & & \\
\hline Luo et al. & $<24$ mon & $\begin{array}{l}5.8 \text { mon } \\
(60.2 \%)\end{array}$ & $\begin{array}{l}4 \mathrm{~mL}(n \\
=50)\end{array}$ & $\begin{array}{l}+2.5 \mathrm{mg} \\
\text { salbutamol }\end{array}$ & $\begin{array}{l}4 \mathrm{~mL}(n= \\
43)\end{array}$ & $\begin{array}{l}+2.5 \mathrm{mg} \\
\text { salbutamol }\end{array}$ & \\
\hline 2010 & Inpatients & $69.9 \%$ & & & & & CSS \\
\hline China & $n=93$ & & & & & & \\
\hline & $<24$ mon & $\begin{array}{l}5.9 \text { mon } \\
(56.3 \%)\end{array}$ & $\begin{array}{l}4 \mathrm{~mL}(n \\
=57)\end{array}$ & & $\begin{array}{l}4 \mathrm{~mL}(n= \\
55)\end{array}$ & & \\
\hline 2011 & Inpatients & $720 \%$ & & & & & CSS \\
\hline China & $n=112$ & & & & & & \\
\hline $\begin{array}{l}\text { Mahesh Kumar } \\
\text { et al. }\end{array}$ & $<24$ mon & $\begin{array}{l}5.9 \text { mon } \\
(62.5 \%)\end{array}$ & $\begin{array}{l}3 \mathrm{~mL}(n \\
=20)\end{array}$ & $\stackrel{+}{0.15 \mathrm{mg} / \mathrm{kg}}$ & $\begin{array}{l}3 \mathrm{~mL}(n= \\
20)\end{array}$ & $\stackrel{+}{0.15 \mathrm{mg} / \mathrm{kg}}$ & LOS \\
\hline 2013 & Inpatients & & & albuterol & & albuterol & \\
\hline India & $n=40$ & information & & & & & \\
\hline Mandelbera et & $<12$ mon & $29 \mathrm{mon}$ & $4 \mathrm{ml} / \mathrm{n}$ & +1 & $4 \mathrm{ml}(n=$ & $+1>$ & 105 \\
\hline al. & I & $(57.7 \%)$ & $=27)$ & epinephrine & 25) & epinephrine & con \\
\hline 2003 & 10 & $86.5 \%$ & & & & & \\
\hline Israel & & & & & & & \\
\hline Miraglia et al. & $<24$ mon & $\begin{array}{l}4.5 \mathrm{mon} \\
(65.1 \%)\end{array}$ & $\begin{array}{l}4 \mathrm{~mL}(n \\
=52)\end{array}$ & $\begin{array}{l}+1.5 \mathrm{mg} \\
\text { epinephrine }\end{array}$ & $\begin{array}{l}4 \mathrm{~mL}(n= \\
54)\end{array}$ & $\begin{array}{l}+1.5 \mathrm{mg} \\
\text { epinephrine }\end{array}$ & LOS \\
\hline 2012 & Inpatients & $82 \%$ & & & & & CSS \\
\hline Italy & $n=106$ & & & & & & \\
\hline Morikawa et al. & $<12$ mon & $\begin{array}{l}4.3 \mathrm{mon} \\
(39 \%)\end{array}$ & $\begin{array}{l}2 \mathrm{~mL}(n \\
=63)\end{array}$ & $+0.5 \%$ & $\underset{65)}{2 \mathrm{~mL}}(n=$ & $+0.5 \%$ & LOS \\
\hline 2018 & Inpatients & & & salbutamol & & salbutamol & \\
\hline Japan & $n=128$ & information & & & & & \\
\hline 1. ED, emerger & artmen & D, outpatie & partm & SSV, respira & syncytial v & & \\
\hline 2. $3 \% \mathrm{HS}, 3 \%$ hyp & ertonic salir & $0.9 \%$ NS, $0.9 \%$ & normal sal & & & & \\
\hline $\begin{array}{l}\text { 3. Epinephrine: A } \\
\text { Corticosteroids. }\end{array}$ & Irenaline; Atr & vent, Salbutan & ol, Albuterc & Terbutaline: B & onchodilato & Budesonide: & \\
\hline $\begin{array}{l}\text { 4. CSS, clinical s } \\
\text { ROH, rate of hos } \\
\text { the night. }\end{array}$ & $\begin{array}{l}\text { erity score } \\
\text { alization; }\end{array}$ & $\begin{array}{l}\text { Al, respirator } \\
\text {, rate of re-ac }\end{array}$ & $\begin{array}{l}\text { distress a } \\
\text { mission; } T\end{array}$ & $\begin{array}{l}\text { sessment ins } \\
S \text {, time of sle }\end{array}$ & $\begin{array}{l}\text { ment; LOS, I } \\
\text { ng; FOWITN }\end{array}$ & $\begin{array}{l}\text { gth of hospit } \\
\text { requency of } n\end{array}$ & $\begin{array}{l}\text { stay; } \\
\text { king up in }\end{array}$ \\
\hline
\end{tabular}




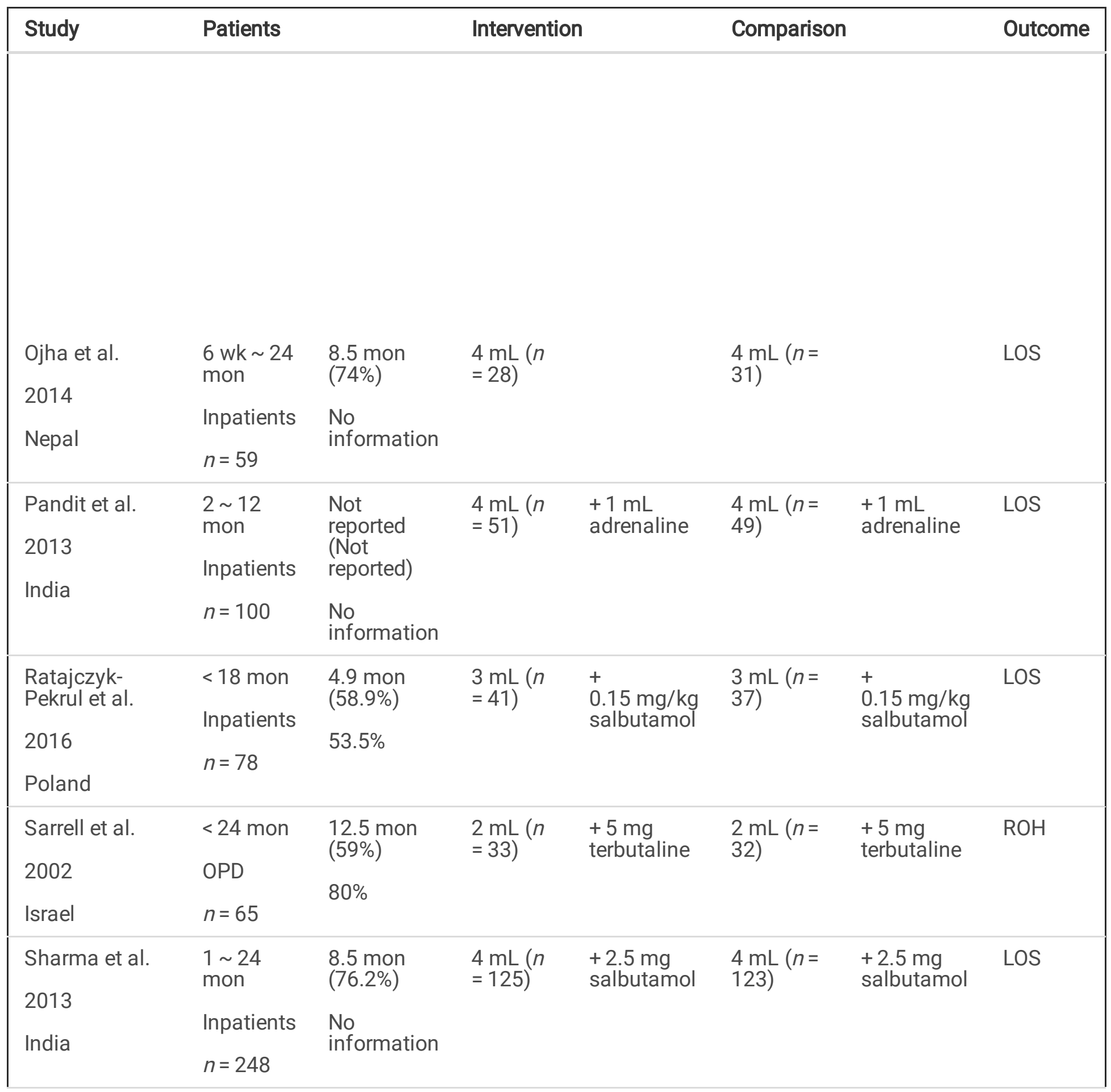

1. ED, emergency department; OPD, outpatient department; RSV, respiratory syncytial virus.

2. $3 \% \mathrm{HS}, 3 \%$ hypertonic saline; $0.9 \% \mathrm{NS}, 0.9 \%$ normal saline.

3. Epinephrine: Adrenaline; Atrovent, Salbutamol, Albuterol, Terbutaline: Bronchodilator; Budesonide: Corticosteroids.

4. CSS, clinical severity score; RDAl, respiratory distress assessment instrument; LOS, length of hospital stay; $\mathrm{ROH}$, rate of hospitalization; ROR, rate of re-admission; TOS, time of sleeping; FOWITN, frequency of waking up in the night. 


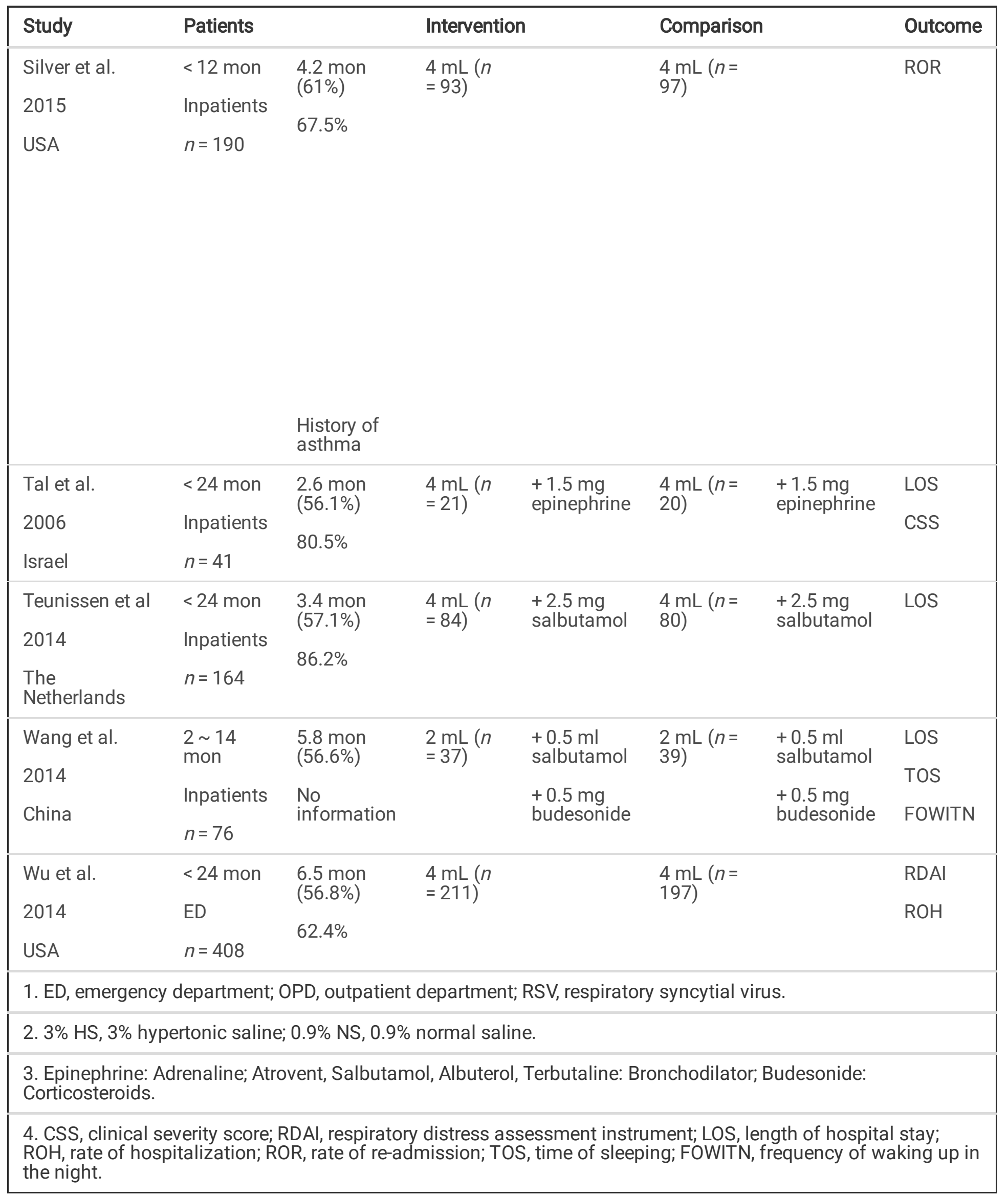

\section{lii. Quality Assessment of The Included Literature}


According to the Cochrane risk of bias tool 2.0, quality assessment results of the included literature showed the following results: (1) For bias arising from the randomization process, 20 (62.5\%) studies used the computer for random grouping and used a light-proof envelope to keep the groups hidden during the process; 11 studies (34.4\%) did not clearly explain randomization or hidden process, whereas one study (3.1\%) grouped subjects according to the order of admission, which did not meet randomization requirements and was assessed to be with high risk of bias. (2) For bias due to deviations from the intended intervention, both subjects and caretakers in 23 studies (71.9\%) were blinded, six studies (18.8\%) had no information on whether blinding was performed, and three studies (9.4\%) indicated that neither subjects nor caretakers were blinded, and therefore, these were assessed to be with high risk of bias. (3) For bias due to missing outcome data, 20 studies (62.5\%) conformed to the intention-to-treat principle, and although there were certain data losses during the study process, those did not affect the balance of the subjects' basic characteristics, and these were determined to be with low risk of bias; five studies (15.6\%) had no information on whether loss of data affected the results, and these were assessed to be with some concern of bias. (4) For bias in measurement of the outcome, research personnel were the ones who measured the severity of respiratory distress, and it was not explained whether the evaluators were blinded. Thus, this could have caused some bias in measurement outcomes, and it was assessed to be with some concern of bias. (5) No situations of bias in selection of the reported results were found in the included articles, and the articles were assessed to be with low risk of bias. Finally, for overall assessment, seven studies (21.9\%) showed low risk of bias, 21 studies (65.6\%) showed some concern of bias, and four studies (12.5\%) showed high risk of bias. Overall assessment result of the literature was some concern of bias, the details of which are demonstrated in Fig. 2.

GRADE was used to assess the evidence body of the included literature. The study included RCTs such that the starting evidence grade was high. However, regarding the severity level of respiratory distress, the evidence level was degraded considering that the overall risk assessment results indicated some concern about bias. With regards to the severity of respiratory distress, the Clinical Severity Score (CSS) was used to assess the severity of respiratory distress, and a forest plot was used to demonstrate the high heterogeneity $(R>75 \%)$. Thus, the evidence level was degraded owing to inconsistency. Regarding the LOS, considering that the overall risk assessment results showed bias with some concern and the forest plot also showed high heterogeneity $(R>75 \%)$, the evidence level was degraded owing to risk of bias and inconsistency, and the overall evidence level was moderately low, with details summarized in Table 2. Lastly, in accordance with the evidence that the intervention measure could significantly improve the severity of respiratory distress and shorten the LOS while causing no severe adverse effects, results showed that the benefits outweighed the risks, and this practice could be strongly recommended.

Table 2. Summary of findings using GRADE. 


\begin{tabular}{|c|c|c|c|c|c|c|}
\hline \multicolumn{7}{|c|}{$3 \%$ Hypertonic Saline compared to $0.9 \%$ Normal Saline for ped bronchit is } \\
\hline \multicolumn{7}{|c|}{$\begin{array}{l}\text { Patient or population: ped bronchitis } \\
\text { Setting: } \\
\text { Intervention: } 3 \% \text { Hypertonic Saline } \\
\text { Comparison: } 0.9 \% \text { Normal Saline }\end{array}$} \\
\hline \multirow[b]{2}{*}{ Outcomes } & \multicolumn{2}{|c|}{$\begin{array}{l}\text { Anticipated abs olute } \\
\text { effects }(95 \% \mathrm{Cl})\end{array}$} & \multirow[b]{2}{*}{$\begin{array}{l}\text { Relative } \\
\text { effect } \\
(95 \% \mathrm{C})\end{array}$} & \multirow[b]{2}{*}{$\begin{array}{c}\text { Ne of } \\
\text { partidpants } \\
\text { (studles) }\end{array}$} & \multirow{2}{*}{$\begin{array}{l}\text { Certainty } \\
\text { of the } \\
\text { evidence } \\
\text { (GPADC) }\end{array}$} & \multirow[b]{2}{*}{ Comments } \\
\hline & $\begin{array}{l}\text { Risk with } \\
0.9 \% \\
\text { Normal } \\
\text { Saline }\end{array}$ & $\begin{array}{l}\text { Risk with } \\
3 \% \\
\text { Hyperto nic } \\
\text { Saline }\end{array}$ & & & & \\
\hline CSS & $\begin{array}{l}\text { The mean } \\
\text { CSS was - } \\
\mathbf{3 . 5 7} \text { to } 8.8 \\
\text { point }\end{array}$ & $\begin{array}{l}\text { MO } 1 \text { point } \\
\text { lower } \\
\text { (1.29 lower } \\
\text { to } 0.72 \\
\text { lower) }\end{array}$ & $\cdot$ & $\begin{array}{l}2010 \\
\text { (11 RCTs) }\end{array}$ & $\begin{array}{l}\oplus \oplus O O \\
\text { Low }=0\end{array}$ & \\
\hline RDA & $\begin{array}{l}\text { The mean } \\
\text { RDA was - } \\
\mathbf{4 . 7} \text { to } \mathbf{5 . 3 2} \\
\text { point }\end{array}$ & $\begin{array}{l}\text { MD } 0.6 \\
\text { point } \\
\text { lower } \\
(0.95 \text { lower } \\
\text { to } 0.26 \\
\text { lower) }\end{array}$ & $\cdot$ & $\begin{array}{c}1369 \\
\text { (5 RCTs) }\end{array}$ & $\begin{array}{l}\text { Ф๑९O } \\
\text { MODERATE }\end{array}$ & \\
\hline LOS & $\begin{array}{l}\text { The mean } \\
\text { LOS was } \\
\mathbf{1 . 4} \text { to } 7.49 \\
\text { days }\end{array}$ & $\begin{array}{l}\text { MD } 0.54 \\
\text { days lower } \\
(0.86 \text { lower } \\
\text { to } 0.23 \\
\text { lower })\end{array}$ & $\cdot$ & $\begin{array}{l}2055 \\
(20 \text { ACTs) }\end{array}$ & $\begin{array}{c}\oplus \oplus O O \\
\text { LOW }=0\end{array}$ & \\
\hline $\begin{array}{c}\text { Rate of } \\
\text { hospitalis ation }\end{array}$ & $\begin{array}{l}402 \text { per } \\
1.000\end{array}$ & $\begin{array}{l}329 \text { per } \\
1,000 \\
(284 \text { to } \\
377)\end{array}$ & $\begin{array}{c}\text { OR } 0.73 \\
(0.59 \text { to } \\
0.90)\end{array}$ & $\begin{array}{l}1710 \\
\text { (8 RCTs) }\end{array}$ & $\begin{array}{l}\text { Ф๑९O } \\
\text { MODERATE } \\
\text { a }\end{array}$ & \\
\hline $\begin{array}{l}\text { Rate of re- } \\
\text { admission }\end{array}$ & $\begin{array}{l}135 \text { per } \\
1,000\end{array}$ & $\begin{array}{l}96 \text { per } \\
1,000 \\
(48 \text { to } \\
184)\end{array}$ & $\begin{array}{c}\text { OR } 0.68 \\
(0.32 \text { to } \\
1.44)\end{array}$ & $\begin{array}{l}485 \\
\text { (4 RCTs) }\end{array}$ & $\begin{array}{l}\text { ๑๑ФО } \\
\text { MODERATE }\end{array}$ & \\
\hline $\begin{array}{l}\text { Time of } \\
\text { sleeping }\end{array}$ & $\begin{array}{c}\text { The mean } \\
\text { time of } \\
\text { sleeping } \\
\text { was } \mathbf{4 . 5 4} \\
\text { to } \mathbf{7 . 3 2} \\
\text { hour }\end{array}$ & $\begin{array}{c}\text { M } 1.72 \\
\text { hour } \\
\text { higher } \\
(0.43 \text { lower } \\
\text { to } 3.88 \\
\text { higher) }\end{array}$ & $\cdot$ & $\begin{array}{l}110 \\
\text { (2 RCTs) }\end{array}$ & $\underset{\text { LOW }}{\oplus \oplus, 0}$ & \\
\hline $\begin{array}{c}\text { Frequency of } \\
\text { wake-up in the } \\
\text { night }\end{array}$ & $\begin{array}{c}\text { The mean } \\
\text { frequency } \\
\text { of wake-up } \\
\text { in the night } \\
\text { was } \mathbf{3 . 1 1} \\
\text { to } 9.28 \\
\text { time }\end{array}$ & $\begin{array}{l}\text { MD } 5.61 \\
\text { time lower } \\
\text { (6.54 lower } \\
\text { to } 4.67 \\
\text { lower) }\end{array}$ & $\cdot$ & $\begin{array}{c}110 \\
\text { (2 RCTs) }\end{array}$ & $\begin{array}{l}\text { Ф๑ФО } \\
\text { MODERATE }\end{array}$ & \\
\hline \multicolumn{7}{|c|}{$\begin{array}{l}\text { The risk in the interve ntion group (and its } 95 \% \text { confidence interval) is based on the as sumed risk in the } \\
\text { comparison group and the relative effect of the intervention (and its } 95 \% \mathrm{CI} \text { ). }\end{array}$} \\
\hline \multicolumn{7}{|c|}{ Cl: Confidence interval; MD: Mean difference: OR: Odds ratio } \\
\hline \multicolumn{7}{|c|}{ 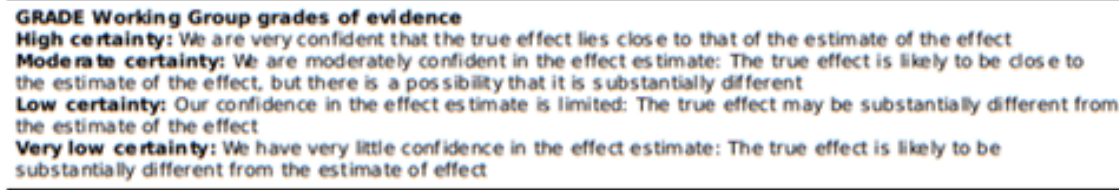 } \\
\hline
\end{tabular}

a. The overall of risk of bias was of some concern.

b. $R>75 \%$ (statistically significant).

\section{Meta-analytical Results \\ (1) Primary Results: Severity of Respiratory Distress}

Regarding the severity of respiratory distress, the included studies used the CSS and Respiratory Distress Assessment Instrument (RDAl) for evaluation.

\section{Clinical Severity Score (CSS)}


In total, 11 studies used the CSS for evaluation. According to differences in days of measurement for each study (ranging $1 \sim 3$ days), four subgroups were used for analysis as follow: $<1$ day of measurement $(n=2$, participants $=$ $249), 1$ or 2 days of measurement ( $n=8$, participants $=656), 2$ or 3 days of measurement $(n=8$, participants $=581)$, and $>3$ days of measurement $(n=7$, participants $=524)$. Results showed that compared to the group that used normal saline, the group that used $3 \%$ hypertonic saline for nebulizing treatment had significantly greater differences in the score for respiratory distress severity for the subgroups of $1 \sim 2,2 \sim 3$, and > 3 days with 0.71 points (95\% Cl: $-1.15,-0.27, P=73 \%), 1.19$ points ( $95 \% \mathrm{Cl}:-1.84,-0.54, P=87 \%)$, and 1.38 points ( $95 \% \mathrm{Cl}:-1.68,-1.07, P=49 \%)$, respectively. Only the subgroup which had $<1$ day of measurement did not show a statistically significant difference between the two test groups (MD: $-0.30,95 \% \mathrm{Cl}:-1.37,0.76,2=93 \%$ ). Data are shown in Fig. 3.

\section{Respiratory Distress Assessment Instrument (rdai)}

In total, five papers used the RDAl for evaluation. There were 1369 subjects in total, and the meta-analytical results showed that compared to the group that used normal saline, those that used hypertonic saline for nebulizing treatment had a mean 0.6 points lower score for respiratory distress severity $(95 \% \mathrm{Cl}:-0.95,-0.26, P=0 \%)$, as demonstrated in Fig. 4.

\section{(2) Secondary Results}

\section{Length Of Hospital Stay (los)}

In total, 20 studies were included with 2055 subjects. Meta-analytical results showed that compared to the group that used normal saline, those that used hypertonic saline for nebulizing treatment had a 0.54-day shorter LOS (95\% $\mathrm{Cl}:-0.86,-0.32, P=81 \%)$, as demonstrated in Fig. 6 . Because this result was highly heterogeneous, further subgroup analyses were performed with respect to different regions, which greatly reduced the heterogeneity: the Americas and Europe $(R=0 \%)$, Asia (excluding China) $(R=48 \%)$, and China $(R=0 \%)$, as demonstrated in Fig. 5 .

\section{Rate of Hospitalization}

In total, eight studies were included with 1710 subjects. Meta-analytical results showed that compared to the group that used normal saline, those that used hypertonic saline for nebulizing treatment had significantly lower rates of hospitalization (OR: 0.73, 95\% Cl: 0.59, 0. 90, $₹=0 \%$ ), as shown in Fig. 6.

\section{Rate of Readmission}

In total, four studies were included with 485 subjects. Meta-analytical results showed that compared to the group that used normal saline, those that used hypertonic saline for nebulizing treatment had lower rates of readmission (OR: $0.68,95 \% \mathrm{Cl}$ : 0.32, 1.44, $R=33 \%$ ), but it did not reach statistical significance, as shown in Fig. 7.

\section{Time of Sleeping}


Two studies were included with 110 subjects. Meta-analytical results showed that compared to the group that used normal saline, those that used hypertonic saline for nebulizing treatment had 1.72 hours longer sleep time at night (95\% Cl: $-0.43,-3.88, R=91 \%)$, but this did not reach statistical significance, as shown in Fig. 8.

\section{Frequency of Waking Up In The Night}

Two studies were included with 110 subjects. Meta-analytical results showed that compared to the group that used normal saline, those that used hypertonic saline for nebulizing treatment demonstrated effectively reduced the frequency of waking up in the night by five times (95\% Cl: $\left.-6.54,-4.67,{ }^{2}=0 \%\right)$, as shown in Fig. 9.

\section{Adverse Events}

Twelve studies reported mild adverse events, including cough $28,32,40,55,57,59$, bronchospasm 40,57 , vomiting and diarrhea $^{34,51}$, desaturation ${ }^{57}$, agitation ${ }^{41,57}$, rhinorrhea ${ }^{28}$, tachycardia ${ }^{58}$, hoarse voices ${ }^{44}$, vigorous crying ${ }^{41}$, vomiting and diarrhea ${ }^{34,51}$. One study ${ }^{27}$ reported serious adverse event (bradycardia and desaturation) in hypertonic saline group. However, these were mild and resolved naturally and all subjects completed the trial process.

\section{Sensitivity Analysis Results}

Because the forest plot for LOS showed high heterogeneity, we conducted a sensitivity analysis regarding this and used research method differences (PICO) for a subgroup analysis. First, grouping was conducted based on whether there was combined use of other drugs. Results after grouping showed no significant effects on the overall results. However, when a subgroup analysis was done for different regions (Americas, Europe, China, and other Asian countries), it was found that the heterogeneity greatly decreased, and high heterogeneity existed among groups $(R=$ $95.6 \%)$, demonstrating that this was the cause for the high heterogeneity.

\section{Analysis Of Publication}

We conduct the publication analysis of studies which were included, because we had pool more than 10 trials. We created and examined a funnel plot to explore possible publication bias. There appeared to be no evidence of publication bias in the included studies.

\section{Discussion}

Results of the meta-analyses in this study showed that compared to the use of normal saline and regardless of whether or not children were hospitalized, the use of hypertonic saline for nebulizing treatment improved the severity of respiratory distress, extended the sleep time, reduced the frequency of waking up during the night, and shortened the children's LOS. For non-hospitalized children, it also reduced the rate of hospitalization.

All subjects included in the trials were diagnosed with acute bronchiolitis, and there were no significant differences in the sex ratio. However, the severity of respiratory syncytial virus (RSV) infection was inconsistent, and this may have affected the effects of the interventions. Additionally, all subjects in the study were children aged $<2$ years, and only one study included subjects aged between 6 months and 5 years old. However, the measurement results for 
respiratory distress severity in that particular study were recorded as median and quartiles and could not be included in data calculations. Therefore, that study was excluded from the meta-analysis. The study only included subjects aged $<2$ years for analysis; therefore, additional research will be required to verify whether the study results are suitable for children aged $>2$ years.

There were differences in the intervention measures in each of the studies included. The nebulization treatment time lasted for $20 \sim 30 \mathrm{~min}$, but the saline dosage used for nebulizing ranged from 2 to $5 \mathrm{~mL}$. In addition, for subjects with different clinical symptoms, most studies combined treatment with epinephrine, bronchodilators, or steroids. Although this may have affected the treatment results, it was an unavoidable variable owing to treatment needs. Regarding this, the study conducted subgroup analyses on the aforementioned two variables (saline dosage and drug combinations). It was found that neither of these variables were the cause of the high heterogeneity. Related literature also pointed out that combined drugs were not the primary reasons interfering with the efficacy of results. ${ }^{60-62}$

The primary result in this study was respiratory distress severity. Results demonstrated no significant difference in disease improvement for < 1 day of nebulizing treatment; however, with a longer duration of nebulizing treatment with hypertonic saline, improvements in respiratory distress severity scores were more significant. We speculated that the following two reasons could be the causes for this effect: it takes $>1$ day for hypertonic saline to reach its efficacy, and after children are hospitalized and treated, their autoimmunity and body strength recover along with an increase in the treatment duration, and the disease severity is gradually ameliorated along with the disease course, thus showing more-significant treatment efficacy. ${ }^{63-65}$

Additionally, study results also showed that those who used hypertonic saline for nebulizing treatment compared to those who used normal saline had 0.54 fewer days of LOS. It was statistically significant, although the amount of decline is small, and this is a huge breakthrough in clinical hospitals which are usually saturated. It was observed in studies on Chinese subjects that they had longer LOSs than studies conducted in other countries, and it was speculated that this was related to differences in local customs and insurance systems. National cultural differences may have also been influential ${ }^{30,43-45}$, but this would require further research for verification.

Sleep quality is relatively important for children's mental and physical strength. ${ }^{14-16}$ This is the first study to analyze sleep quality (including sleep time and frequency of waking up at night) in children with bronchiolitis undergoing nebulizing treatment. Among the five studies of Chinese subjects included, only two investigated night-time sleep quality. ${ }^{35,58}$ In two articles, it was pointed out that the sleep time and frequency of waking up at night (opening eyes as the calculation standard) were recorded by the nurse and family from 8 pm to the next day 8 am. Results showed that hypertonic saline was effective in reducing the frequency of waking up at night. Although the results did not reach significance regarding sleep time, this was still a major breakthrough regarding investigation of sleep quality, and we suggest that future clinical trials include sleep quality as a result index for measurement.

\section{Limitations}

The study had three main limitations: (1) inconsistent disease severity in the included subjects; (2) differences between studies with respect to dosage of hypertonic saline used for the intervention and the combined use of drugs such as bronchodilators; and (3) evaluators who determined the severity of respiratory distress were medical personnel or research personnel, but the evaluators were not blinded. All these factors may have affected the quality of the study results. 


\section{Conclusions}

Using hypertonic saline for nebulizing treatment in children with bronchiolitis can significantly improve the severity of respiratory distress, shorten the LOS, and increase the children's night-time sleep quality. Owing to differences in disease severity and intervention dosages for subjects included in this study, it is recommended that a large-scale randomized clinical trial with a standardized design be conducted in the future to investigate the effects of hypertonic saline in children with bronchiolitis so that the results are complete.

\section{Abbreviation}

1. ED, emergency department

2. OPD, outpatient department

3. RSV, respiratory syncytial virus.

4. $3 \% \mathrm{HS}, 3 \%$ hypertonic saline

5. $0.9 \%$ NS, $0.9 \%$ normal saline.

6. CSS, clinical severity score

7. RDAl, respiratory distress assessment instrument

8. LOS, length of hospital stay

9. $\mathrm{ROH}$, rate of hospitalization

10. ROR, rate of re-admission

11. TOS, time of sleeping

12. FOWITN, frequency of waking up in the night.

\section{Declarations}

\section{Contribution To Authorship}

CW Hsieh, HC Su, KH Chen and C Chen helped with design and modification of study protocol. CW Hsieh and HC Su searched the database. CW Hsieh and HC Su screened, data extraction and risk of bias assessment. KH Chen and C Chen analyzed and interpreted the data and wrote the first draft. $\mathrm{KH}$ Chen and $\mathrm{C}$ Chen helped with critical revision of the study results, and with modifications necessary for the final version to be published. All authors contributed to subsequent versions and approved the final article.

\section{Acknowledgements}

We thank Yu-Ting Huang at the Medical Library, Wanfang Medical Center, Taipei Medical University, Taiwan, who established comprehensive search strategies.

\section{Funding/Support statement}

Funding for this research was provided mainly by Taipei Medical University (no. TMU106-AE1-B12) and Taiwan Ministry of Science and Technology (MOST 107-2320-B038-018-MY2). 


\section{Declaration of interest}

The authors declare no conflicts of interests relevant to this article.

\section{References}

1. Meissner HC. Selected populations at increased risk from respiratory syncytial virus infection. Pediatr Infect Dis J. 2003;22(2):40-5.

2. Shi T, McAllister DA, O'Brien KL, Simoes EA, Madhi SA, Gessner BD, ... Alassani I. Global, regional, and national disease burden estimates of acute lower respiratory infections due to respiratory syncytial virus in young children in 2015: a systematic review and modelling study. The Lancet. 2017;390(10098):946-58.

3. Chou T, Chen E, Liu Y, Wu I, Chien M, Hsiao H, Lai S. (2018). A comparison study: Treat acute bronchiolitis infants with hypertonic saline by small volume jet nebulizer and portable vibrating-mesh nebulizer. Am J Respir Crit Care Med, 197(MeetingAbstracts).

4. Ozdogan S, Koker O, Kose G, Yildirmak Y. (2014). The efficacy of nebulized hypertonic saline in acute bronchiolitis in hospital setting: A randomized and double blind trial. Am J Respir Crit Care Med, 189.

5. Journal of clinical virology, 35(4), 463-466.

6. Rose RM, Pinkston P, O'Donnell C, Jensen WA. Viral infection of the lower respiratory tract. Clin Chest Med. 1987;8(3):405.

7. Chen YJ, Lee WL, Wang CM, Chou HH. Nebulized hypertonic saline treatment reduces both rate and duration of hospitalization for acute bronchiolitis in infants: an updated meta-analysis. Pediatr Neonatol. 2014;55(6):4318. doi:10.1016/j.pedneo.2013.09.013.

8. Everard ML, Hind D, Freeman JV, Bradburn M. (2014). Hypertonic saline in acute bronchiolitis: Randomised controlled trial (RCT) and economic evaluation (the SABRE study). European respiratory journal, 44.

9. Meissner HC. Selected populations at increased risk from respiratory syncytial virus infection. Pediatr Infect Dis J. 2003;22(2):40-5.

10. Panitch HB, Callahan JC, Schidlow DV. Bronchiolitis in children. Clin Chest Med. 1993;14(4):715-31.

11. Florin TA, Plint AC, Zorc JJ. Viral bronchiolitis. The Lancet. 2017;389(10065):211-24.

12. Wohl ME, Chernick V. State of the art: bronchiolitis. Am Rev Respir Dis. 1978;118(4):759-81.

13. Brezinova V, Simpson H. Sleep apnoea in acute bronchiolitis. Arch Dis Child. 1982;57(6):467-72.

14. Pratl B, Steinbrugger B, Weinhandl E, Zach MS. Effect of sleep stages on measurements of passive respiratory mechanics in infants with bronchiolitis. Pediatric pulmonology. 1999;27(4):273-7.

15. Snow A, Dayyat E, Montgomery-Downs HE, Kheirandish-Gozal L, Gozal D. Pediatric obstructive sleep apnea: a potential late consequence of respiratory syncitial virus bronchiolitis. Pediatric pulmonology. 2009;44(12):1186-91.

16. Pediatric pulmonology, 51(3), 308-315.

17. Flores-Gonzalez JC, Comino-Vazquez P, Jimenez-Gómez G, Rodriguez-Campoy P, Matamala-Morillo M, GarciaOrtega R,.. . Lechuga-Sancho AM. Epinephrine versus placebo in hospitalised infants with bronchiolitis treated with hypertonic saline solution. Arch Dis Child. 2014;99:A28-9. doi:10.1136/archdischild-2014-307384.87.

18. Panitch HB. Respiratory syncytial virus bronchiolitis: supportive care and therapies designed to overcome airway obstruction. Pediatr Infect Dis J. 2003;22(2):83-8. 
19. Oymar K, Skjerven HO, Mikalsen IB. Acute bronchiolitis in infants, a review. Scand J Trauma Resusc Emerg Med. 2014;3:22-3.

20. Treatment of acute bronchiolitis.

Wohl MEB, Chernick V. (2003). Treatment of acute bronchiolitis.

21. Zhang L, Ferruzzi E, Bonfanti T, Auler MI, D’avila NE, Faria CS, Costa MM. Long and short-term effect of prednisolone in hospitalized infants with acute bronchiolitis. J Paediatr Child Health. 2003;39(7):548-51.

22. Loza B, Teunissen J, Hochs A, Vaessen-Verberne A, Boehmer A, Smeets C,.. . et al. (2014). Effect of 3 and 6\%hypertonic saline in viral bronchiolitis: a RCT. European respiratory journal, 44.

23. Zhang L, Mendoza-Sassi RA, Wainwright C, Klassen TP. Nebulised hypertonic saline solution for acute bronchiolitis in infants. Cochrane Database Syst Rev. 2013;7:CD006458.

24. Everard ML, Hind D, Ugonna K, Freeman J, Bradburn M, Dixon S,.. . Cross E. Saline in acute bronchiolitis RCT and economic evaluation: hypertonic saline in acute bronchiolitis - randomised controlled trial and systematic review. Health Technol Assess. 2015;19(66):1-130. doi:10.3310/hta19660.

25. Heikkila P, Renko M, Korppi M. Hypertonic saline inhalations in bronchiolitis-A cumulative meta-analysis. Pediatr Pulmonol. 2018;53(2):233-42. doi:10.1002/ppul.23928.

26. Grewal S, Goldman RD. Hypertonic saline for bronchiolitis in infants. Can Fam Physician. 2015;61(6):531-3.

27. Everard ML, Hind D, Ugonna K, Freeman J, Bradburn M, Cooper CL,.. . McNamara PS. SABRE: a multicentre randomised control trial of nebulised hypertonic saline in infants hospitalised with acute bronchiolitis. Thorax. 2014;69(12):1105-12. doi:10.1136/thoraxjnl-2014-205953.

28. Flores P, Mendes AL, Neto AS. A randomized trial of nebulized 3\% hypertonic saline with salbutamol in the treatment of acute bronchiolitis in hospitalized infants. Pediatr Pulmonol. 2016;51(4):418-25. doi:10.1002/ppul.23306.

29. Florin TA, Shaw KN, Kittick M, Yakscoe S, Zorc JJ. Nebulized hypertonic saline for bronchiolitis in the emergency department: a randomized clinical trial. JAMA Pediatr. 2014;168(7):664-70. doi:10.1001/jamapediatrics.2013.5306.

30. Zhang L, Mendoza-Sassi RA, Wainwright C, Klassen TP. (2017). Nebulised hypertonic saline solution for acute bronchiolitis in infants. Cochrane Database of Systematic Reviews, (12).

31. Al-Ansari K, Sakran M, Davidson BL, Sayyed E, Mahjoub R, H., \& Ibrahim K. Nebulized 5\% or 3\% hypertonic or 0.9\% saline for treating acute bronchiolitis in infants. J Pediatr. 2010;157(4):630-4. doi:10.1016/j.jpeds.2010.04.074. 634.e631.

32. Angoulvant F, Bellettre X, Milcent K, Teglas JP, Claudet I, Le Guen CG,.. . Gajdos V. Effect of Nebulized Hypertonic Saline Treatment in Emergency Departments on the Hospitalization Rate for Acute Bronchiolitis: A Randomized Clinical Trial. JAMA Pediatr. 2017;171(8):e171333. doi:10.1001/jamapediatrics.2017.1333.

33. Anil AB, Anil M, Saglam AB, Cetin N, Bal A, Aksu N. High volume normal saline alone is as effective as nebulized salbutamol-normal saline, epinephrine-normal saline, and 3\% saline in mild bronchiolitis. Pediatr Pulmonol. 2010;45(1):41-7. doi:10.1002/ppul.21108.

34. Grewal S, Ali S, McConnell DW, Vandermeer B, Klassen TP. A randomized trial of nebulized 3\% hypertonic saline with epinephrine in the treatment of acute bronchiolitis in the emergency department. Arch Pediatr Adolesc Med. 2009;163(11):1007-12. doi:10.1001/archpediatrics.2009.196.

35. Hou A, Zhang X. [Comparison of the therapeutic effect of different concentrations of aerosolized saline inhalation in the treatment of children with capillary bronchitis]. Chinese Journal of Woman Child Health Research. 2016;3:343-5.

Page 19/30 
36. Ipek IO, Yalcin EU, Sezer RG, Bozaykut A. The efficacy of nebulized salbutamol, hypertonic saline and salbutamol/hypertonic saline combination in moderate bronchiolitis. Pulm Pharmacol Ther. 2011;24(6):633-7. doi:10.1016/j.pupt.2011.09.004.

37. Islam KT, Mollah AH, Matin A, Begum M. Comparative Efficacy of Nebulized 3\% Hypertonic Saline versus $0.9 \%$ Normal Saline in Children with Acute Bronchiolitis. Bangladesh Journal of Child Health. 2018;42(3):130-7.

38. Kanjanapradap T, Deerojanawong J, Sritippayawan S, Prapphal N. Does nebulized hypertonic saline shorten hospitalization in young children with acute viral wheezing? Pediatr Pulmonol. 2018;53(2):138-44. doi:10.1002/ppul.23924.

39. Khanal A, Sharma A, Basnet S, Sharma PR, Gami FC. Nebulised hypertonic saline (3\%) among children with mild to moderately severe bronchiolitis-a double blind randomized controlled trial. BMC Pediatr. 2015;15:115. doi:10.1186/s12887-015-0434-4.

40. Kose S, Sehriyaroglu A, Esen F, Ozdemir A, Kardas Z, Altug U,.. . Kose M. Comparing the Efficacy of 7\%, 3\% and 0.9\% Saline in Moderate to Severe Bronchiolitis in Infants. Balkan Med J. 2016;33(2):193-7. doi:10.5152/balkanmedj.2016.16840.

41. Kuzik BA, Al-Qadhi SA, Kent S, Flavin MP, Hopman W, Hotte S, Gander S. Nebulized hypertonic saline in the treatment of viral bronchiolitis in infants. J Pediatr. 2007;151(3):266-70. doi:10.1016/j.jpeds.2007.04.010. $270 . e 261$.

42. Kuzik BA, Flavin MP, Kent S, Zielinski D, Kwan CW, Adeleye A,.. . Rossi C. Effect of inhaled hypertonic saline on hospital admission rate in children with viral bronchiolitis: a randomized trial. Cjem. 2010;12(6):477-84.

43. Li G, Zhao J. [Effectiveness of inhaled hypertonic saline in children with bronchiolitis]. Zhonghua Er Ke Za Zhi. 2014;52(8):607-10.

44. Luo Z, Fu Z, Liu E, Xu X, Fu X, Peng D,.. . Yang X. Nebulized hypertonic saline treatment in hospitalized children with moderate to severe viral bronchiolitis. Clin Microbiol Infect. 2011;17(12):1829-33. doi:10.1111/j.14690691.2010.03304.x.

45. Luo Z, Liu E, Luo J, Li S, Zeng F, Yang X, Fu Z. Nebulized hypertonic saline/salbutamol solution treatment in hospitalized children with mild to moderate bronchiolitis. Pediatr Int. 2010;52(2):199-202. doi:10.1111/j.1442200X.2009.02941.x.

46. Maheshkumar K, Karunakara B, Nagalli M, Mallikarjuna H. (2013). Aerosolised hypertonic saline in hospitalized young children with acute bronchiolitis: a randomized controlled clinical trial. Journal of Pediatric Sciences, 5.

47. Mandelberg A, Tal G, Witzling M, Someck E, Houri S, Balin A, Priel IE. Nebulized 3\% hypertonic saline solution treatment in hospitalized infants with viral bronchiolitis. Chest. 2003;123(2):481-7. doi:10.1378/chest.123.2.481.

48. Miraglia Del Giudice, M, Saitta F, Leonardi S, Capasso M, Niglio B, Chinellato I,.. . Peroni D. Effectiveness of nebulized hypertonic saline and epinephrine in hospitalized infants with bronchiolitis. Int J Immunopathol Pharmacol. 2012;25(2):485-91. doi:10.1177/039463201202500218.

49. Morikawa Y, Miura M, Furuhata MY, Morino S, Omori T, Otsuka M,.. . Hasegawa Y. Nebulized hypertonic saline in infants hospitalized with moderately severe bronchiolitis due to RSV infection: A multicenter randomized controlled trial. Pediatr Pulmonol. 2018;53(3):358-65. doi:10.1002/ppul.23945.

50. Ojha AR, Mathema S, Sah S, Aryal UR. A comparative study on use of $3 \%$ saline versus $0.9 \%$ saline nebulization in children with bronchiolitis. J Nepal Health Res Counc. 2014;12(26):39-43.

51. Pandit S, Dhawan N, Thakur D. Utility of hypertonic saline in the management of acute bronchiolitis in infants: A randomised controlled study. International Journal of Clinical Pediatrics. 2013;2(1):24-9. 
52. Ratajczyk-Pekrul K, Gonerko P, Peregud-Pogorzelski J. The clinical use of hypertonic saline/salbutamol in treatment of bronchiolitis. Pediatria Polska. 2016;91(4):301-7. doi:10.1016/j.pepo.2016.04.006.

53. Sarrell EM, Tal G, Witzling M, Someck E, Houri S, Cohen HA, Mandelberg A. Nebulized 3\% hypertonic saline solution treatment in ambulatory children with viral bronchiolitis decreases symptoms. Chest. 2002;122(6):2015-20. doi:10.1378/chest.122.6.2015.

54. Sharma BS, Gupta MK, Rafik SP. Hypertonic (3\%) saline vs $0.93 \%$ saline nebulization for acute viral bronchiolitis: a randomized controlled trial. Indian Pediatr. 2013;50(8):743-7.

55. Silver AH, Esteban-Cruciani N, Azzarone G, Douglas LC, Lee DS, Liewehr S,.. . O'Connor K. 3\% Hypertonic Saline Versus Normal Saline in Inpatient Bronchiolitis: A Randomized Controlled Trial. Pediatrics. 2015;136(6):103643. doi:10.1542/peds.2015-1037.

56. Tal G, Cesar K, Oron A, Houri S, Ballin A, Mandelberg A. Hypertonic saline/epinephrine treatment in hospitalized infants with viral bronchiolitis reduces hospitalization stay: 2 years experience. Isr Med Assoc J. 2006;8(3):16973.

57. Teunissen J, Hochs AH, Vaessen-Verberne A, Boehmer AL, Smeets CC, Brackel H,.. . Loza BF. The effect of $3 \%$ and 6\% hypertonic saline in viral bronchiolitis: a randomised controlled trial. Eur Respir J. 2014;44(4):913-21. doi:10.1183/09031936.00159613.

58. Wang S. Nursing research on the effect of high concentration saline inhalation on bronchiolitis. Journal of Qiqihar Medical College. 2014;20:3068-9.

59. Wu S, Baker C, Lang ME, Schrager SM, Liley FF, Papa C,.. . Mason WH. Nebulized hypertonic saline for bronchiolitis: a randomized clinical trial. JAMA Pediatr. 2014;168(7):657-63.

doi:10.1001/jamapediatrics.2014.301.

60. Diarmaid S, Paul M, Anne F, Kenny A, Niamh M, Michael F. (2018). The impact of a change to hospital guidelines on prescribing practices of nebulised 3\% w/v 'hypertonic' saline. Arch Dis Child, 103(2). doi:10.1136/archdischild-2017-314584.51.

61. Gorinova Y, Simonova O, Lashkova Y, Bakradze M. (2014). Hypertonic saline in children with bronchiolitis. European respiratory journal, 44.

62. Koch M, Mentzel H, Ledermüller R. (2015). Inhalation therapy with hypertonic saline (3\%) - A treatment option for airway disease in children? European respiratory journal, 46. doi:10.1183/13993003.congress2015.PA1251.

63. Auger KA, Parker MW, Huang B. (2018). New Method, Same Answer: We Do Not Know if Hypertonic Saline Helps Bronchiolitis. Pediatrics, 142(3). doi:10.1542/peds.2018-1868.

64. Chao JH, Sinert R. Is Nebulized Hypertonic Saline Solution Effective for Acute Bronchiolitis? Ann Emerg Med. 2017;69(1):e1-2. doi:10.1016/j.annemergmed.2016.07.001.

65. Overmann KM, Florin TA. Nebulised hypertonic saline may be less effective than previously reported in reducing hospital length of stay and admission rate in acute bronchiolitis. Evid Based Med. 2016;21(4):143.

doi:10.1136/ebmed-2016-110452.

\section{Figures}




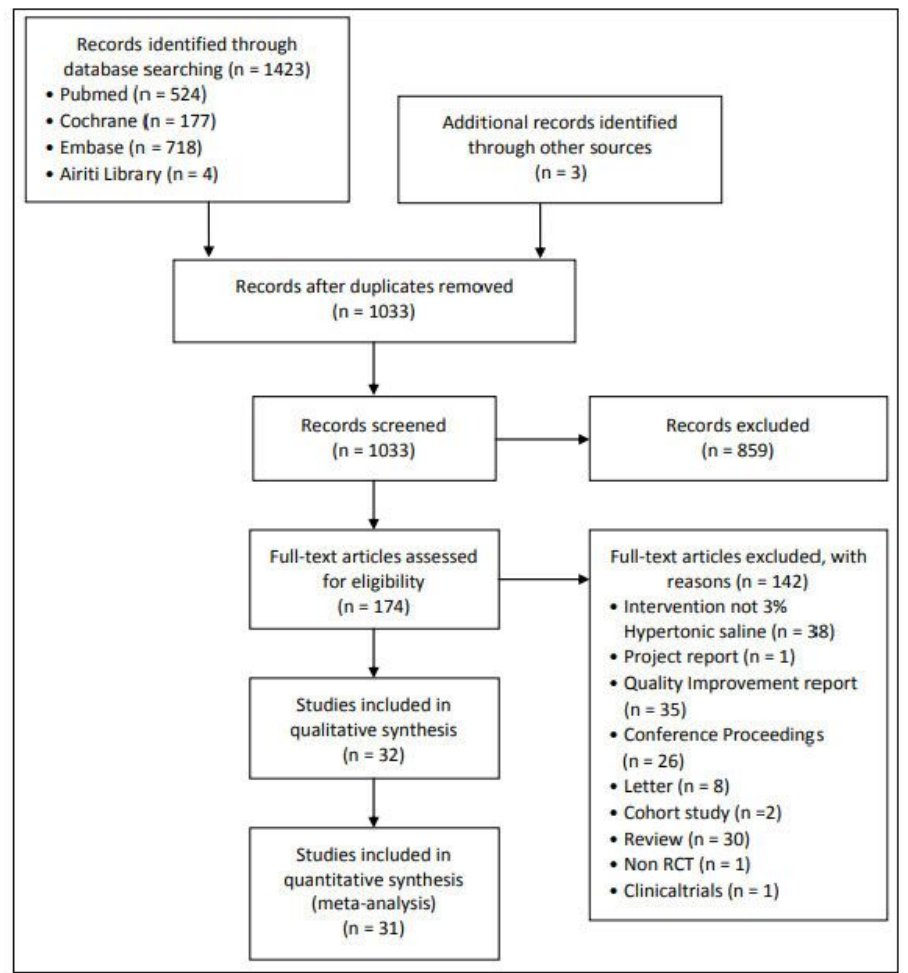

Figure 1. Flow diagram displaying the search process and search results.

Figure 1

Flow diagram displaying the search process and search results. 


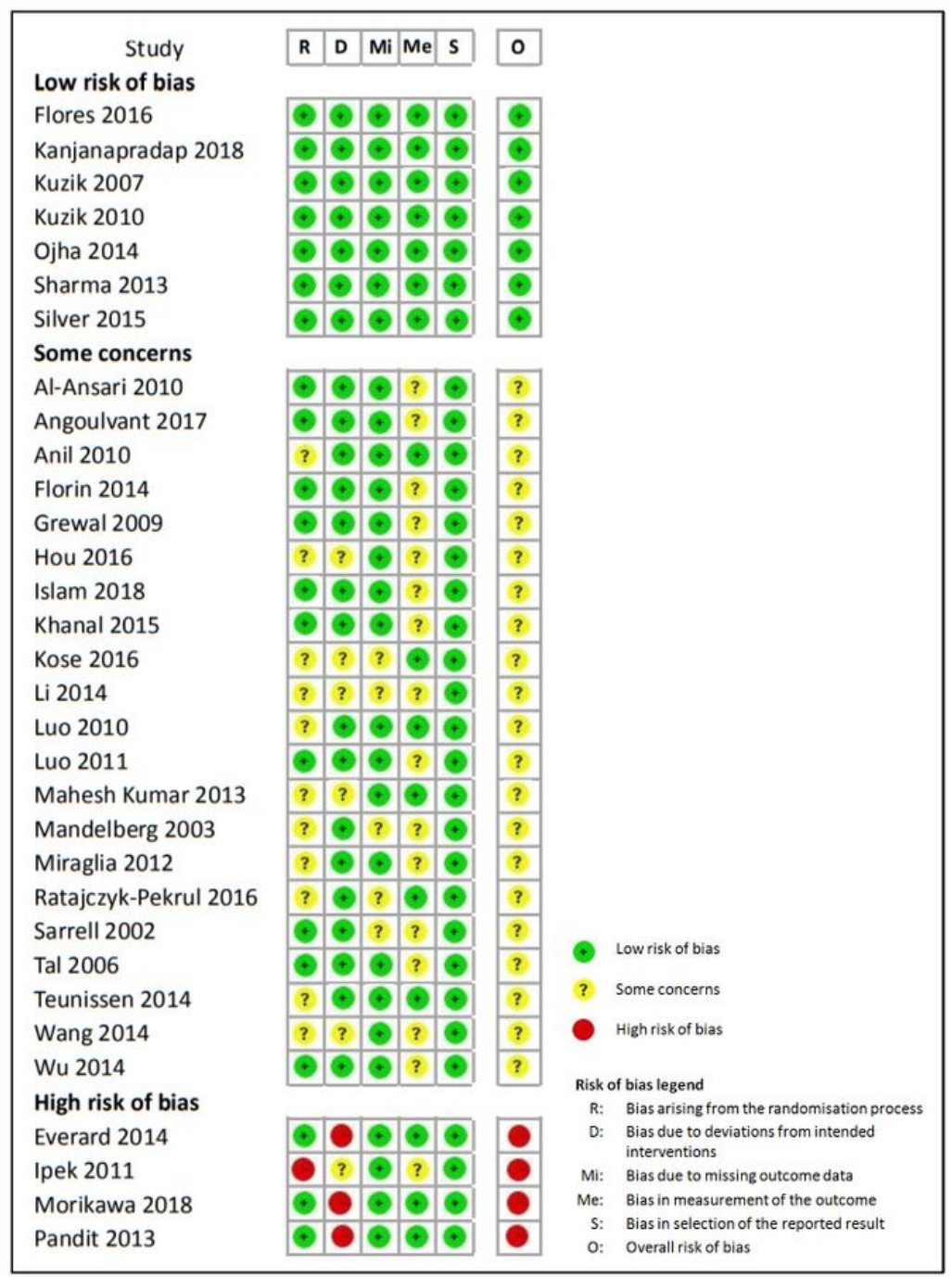

Figure 2. Risk of bias assessment for the included studies.

\section{Figure 2}

Risk of bias assessment for the included studies 


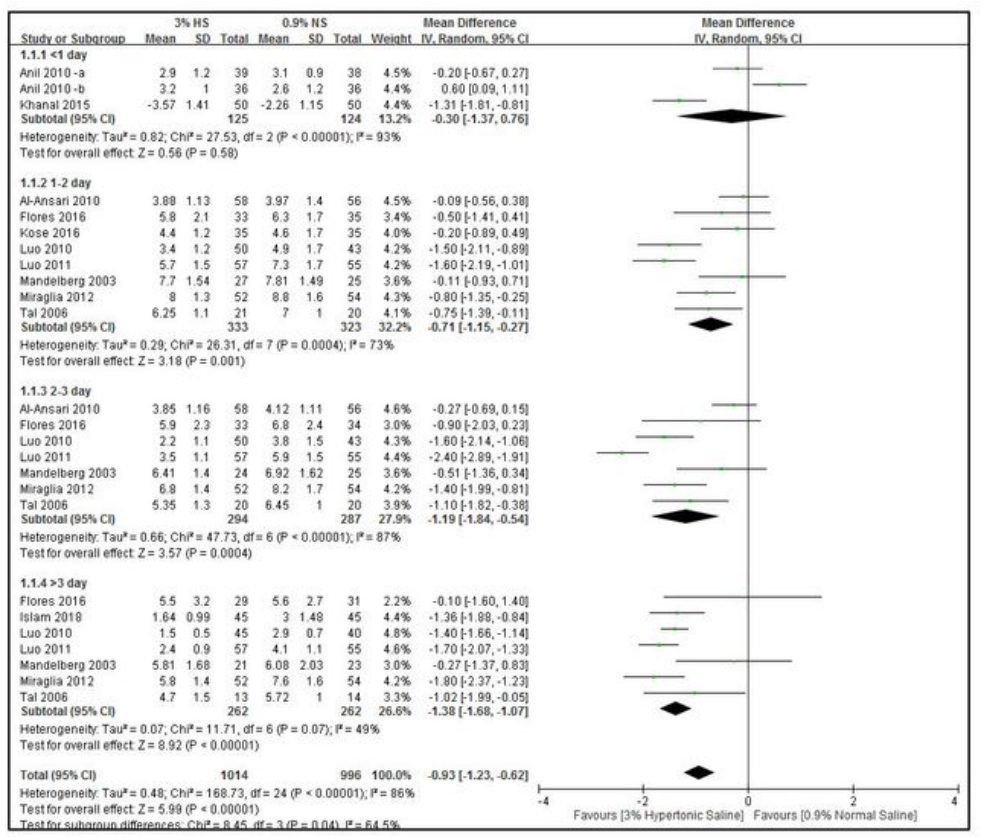

Figure 3: Forest plot of the clinical severity score (CSS): the assessment for testing hypertonic saline vs. normal saline for nebulizing treatment.

\section{Figure 3}

Forest plot of the clinical severity score (CSS): the assessment for testing hypertonic saline vs. normal saline for nebulizing treatment 


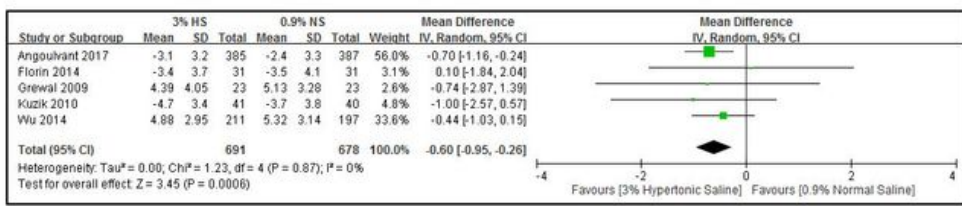

Figure 4: Forest plot of the Respiratory Distress Assessment Instrument (RDAI):

assessment for testing hypertonic saline vs. normal saline for nebulizing treatment.

\section{Figure 4}

Forest plot of the Respiratory Distress Assessment Instrument (RDAl): assessment for testing hypertonic saline vs. normal saline for nebulizing treatment 


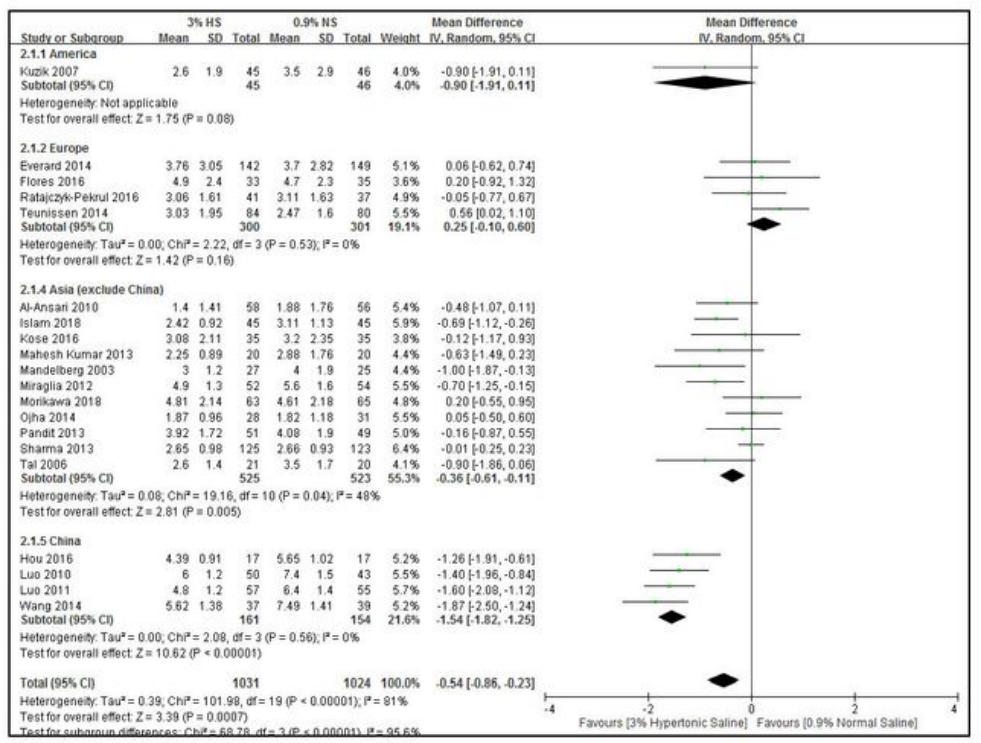

Figure 5: Forest plot of length of hospital stay (LOS): assessment for testing

hypertonic saline vs. normal saline for nebulizing treatment.

\section{Figure 5}

Forest plot of length of hospital stay (LOS): assessment for testing hypertonic saline vs. normal saline for nebulizing treatment 


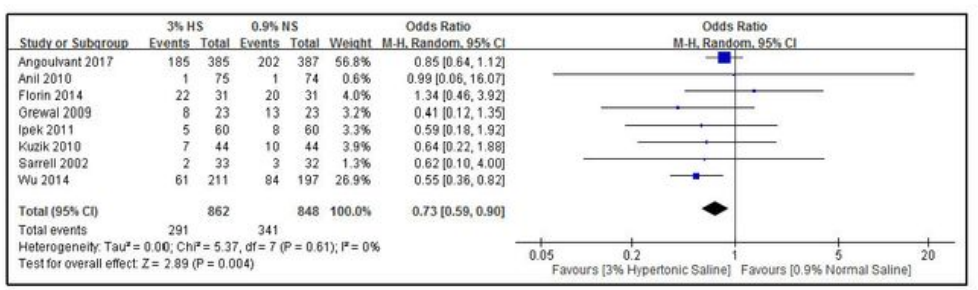

Figure 6: Forest plot of the rate of hospitalization: assessment for testing hypertonic

saline vs. normal saline for nebulizing treatment.

\section{Figure 6}

Forest plot of the rate of hospitalization: assessment for testing hypertonic saline vs. normal saline for nebulizing treatment 


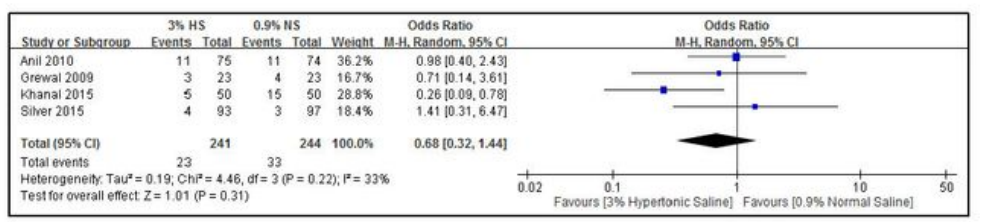

Figure 7: Forest plot of the rate of readmission: assessment for testing hypertonic

saline vs. normal saline for nebulizing treatment.

\section{Figure 7}

Forest plot of the rate of readmission: assessment for testing hypertonic saline vs. normal saline for nebulizing treatment 


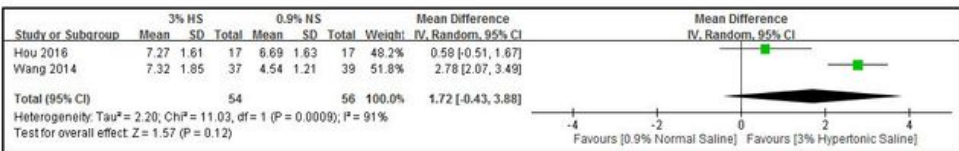

Figure 8: Forest plot of time of sleeping: assessment for testing hypertonic saline vs.

normal saline for nebulizing treatment.

\section{Figure 8}

Forest plot of time of sleeping: assessment for testing hypertonic saline vs. normal saline for nebulizing treatment 


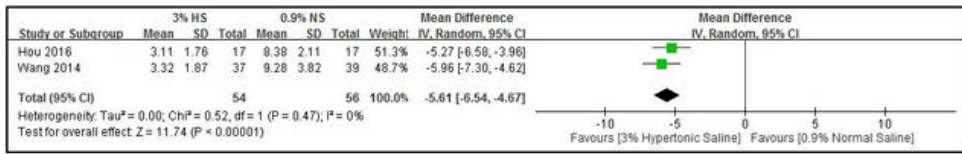

Figure 9: Forest plot of the frequency of waking up in the night: assessment for testing hypertonic saline vs. normal saline for nebulizing treatment.

\section{Figure 9}

Forest plot of the frequency of waking up in the night: assessment for testing hypertonic saline vs. normal saline for nebulizing treatment

\section{Supplementary Files}

This is a list of supplementary files associated with this preprint. Click to download.

- PRISMAchecklist.doc 